\title{
Electrospray Mass Spectrometry for the Analysis of Opioid Peptides and for the Quantification of Endogenous Methionine Enkephalin and $\beta$-Endorphin
}

\author{
Chhabil Dass and Jozef J. Kusmierz \\ Charles B. Stout Neuroscience Mass Spectrometry Laboratory and the Department of Neurology, University \\ of Tennessee-Memphis, Memphis, Tennessee, USA
}

\section{Dominic M. Desiderio}

Charles B. Stout Neuroscience Mass Spectrometry Laboratory and the Departments of Neturology and Biochemistry, University of Tennessee-Memphis, Tennessee, USA

\author{
Stuart A. Jarvis and Brian N. Green \\ VG Masslab, Altrincham, Chesire, WA14 5RZ, UK
}

Electrospray ionization mass spectrometry was used to characterize several different neuropeptides, whose molecular weights ranged from 555 to $3463 \mathrm{Da}$, and to quantify endogenous methionine enkephalin (ME) and $\beta$-endorphin $(\beta E)$ extracted from a human pituitary gland. Methionine enkephalin and leucine enkephalin both yield only an $[\mathrm{M}+\mathrm{H}]^{+}$ion with electrospray mass spectrometry; the other peptides produce a series of multiply charged even-electron molecular ions of the general nature $[\mathrm{M}+n \mathrm{H}]^{n+}$ in proportion to the number of basic amino acid units present, with no evidence of fragmentation. The electrospray mass spectra are characterized by low background noise. The quantification of ME is based on a comparison of the ion current due to the $[\mathrm{M}+\mathrm{H}]^{+}$ion of native and of a deuterated ME ([ ${ }^{2} \mathrm{H}_{5}{ }^{-}$Phe]-ME) internal standard. The calibration curve is linear in the range of ca. 1-35 pmol synthetic ME. The amounts of ME determined in three separate human pituitary extracts were 9.1, 8.2, and $4.7 \mathrm{pmol} / \mathrm{mg}$ protein. The corresponding amount of $\mathrm{ME}$ in a canine pituitary was $39.8 \mathrm{pmol} / \mathrm{mg}$ protein. To quantify $\beta \mathrm{E}$, the ion current due to the $[\mathrm{M}+5 \mathrm{H}]^{5+}$ ion was monitored and compared to an external calibration curve obtained by analyzing solutions of synthetic $\beta \mathrm{E}$ in the range $5 \mathrm{fmol}-50 \mathrm{pmol}$. The analysis of a human pituitary yielded $660 \mathrm{fmol} \beta \mathrm{E} / \mathrm{mg}$ protein. (7 Am Soc Mass Spectrom $1991,2,149-156$ )

$\mathrm{T}$ The focus of current interest in mass spectrometry is to develop ionization methods appropriate for the analysis of biomolecules of ever-increasing molecular size. In the past, the use of mass spectrometry in this field was hampered because these polar, nonvolatile, and thermally labile molecules were not readily accessible to conventional ionization methods. Several so-called soft ionization techniques are in current use to produce intact molecular ions from complex and fragile biomolecular species. Underivatized peptides, proteins, oligonucleotides, carbohydrates, and lipids are being analyzed routinely by fast atom bombardment (FAB) [1], secondary ion mass spectrometry [2], field desorption [3], laser desorption

Address reprint requests to Chhabil Dass and Dominic M. Desiderio, Charles B. Stout Neuroscience Mass Spertrometry Laboratory, Department of Neurology, University of Tennessee-Memphjs, Memphis, TN 38163.
$[4],{ }^{252}$ Cf-plasma desorption [5], and thermospray [6] mass spectrometry.

Recent developments in sample introduction and ionization techniques include electrospray [7-9] and its variation, ion-spray $[10,11]$. The origin of electrospray can be traced back to early pioneering experiments of Dole $[12,13]$. These techniques are capable of producing a series of multiply charged molecular ions, of the general nature $[\mathrm{M}+n \mathrm{H}]^{n+}$, from complex and fragile biomolecules, and no evidence of fragmentation. The benefits of multiple-charging are to extend significantly the usable mass range of a mass spectrometer in proportion to the number of charges on the analyte, and to pernut determination of the molecular weight $\left(M_{r}\right)$ of large biomolecules $[11,14,15]$. For example, the electrospray spectrum of the bovine albumin dimer $\left[\mathrm{M}_{r}=133,000 \mathrm{Da}\right]$ was found to contain ions with over 120 charges [14, 16]. 
Table 1. Neuropeptides investigated by using electrospray mass spectrometry

\begin{tabular}{lrl}
\hline Neuropeptide & $\mathrm{M}_{\gamma}$ & Amino acid sequence \\
\hline \hline Leucine enkephalin (LE) & 555.3 & YGGFL \\
Methionine enkephalin (ME) & 573.2 & YGGFM \\
ME-Lys-Lys & 829.4 & YGGFMKK \\
Dynorphin $A_{1-8}$ & 980.6 & YGGFLRRI \\
Dynorphin $A_{1-9}$ & 1136.7 & YGGFLRRIR \\
Dynorphin $A_{1-10}$ & 1233.7 & YGGFI RRIRP \\
Dynorphin $A_{1-13}$ & 1603.0 & YGGFLRRIRPKLK \\
Dynorphin $A_{1-17}$ & 2146.2 & YGGFLRRIRPKLKWNNO \\
Dynorphin B $_{1-13}$ & 1569.9 & YGGFRROFKVVT \\
B-Endorphin 1-31 & 3462.8 & YGGFMTSEKSOTPLVTLFKNAIIKNAYKKGE \\
\hline
\end{tabular}

In principle, electrospray is an electric field-assisted phenomenon. A solution of the analyte is passed through a metal capillary. A difference in potential of several kilovolts between the capillary and the surrounding chamber charges the surface of the emerging liquid droplets. Coulombic explosion of these evaporating liquid droplets promotes dispersion of the liquid into a fine spray of charged droplets. As this process continues, a concomitant increase in surface charge density produces strong electric fields that facilitate desorption of solute ions.

In this article, we report the use of electrospray to obtain mass spectra of the opioid peptides listed in Table 1 . We have also developed methods to quantify endogenous methionine enkephalin (ME) and $\beta$-endorphin $(\beta E)$ from human pituitary extracts. The quantification of $\mathrm{ME}$ is based on a comparison of the ion currents due to the $[\mathrm{M}+\mathrm{H}]^{+}$ions of $\mathrm{ME}$ and $\left[{ }^{2} \mathrm{H}_{5^{-}}{ }^{4} \mathrm{Phe}\right]-\mathrm{ME}$. To quantify $\beta \mathrm{E}$, the ion current due to the $[\mathrm{M}+5 \mathrm{H}]^{5+}$ ion was monitored and compared to an external calibration curve.

An off-line combination of high-performance liquid chromatography combined with mass spectrometry (HPLC/MS) was used in the present study. Although on-line HPLC/MS in some cases may be superior to off-line HPLC/MS, high liquid flow rates of HPLC have long been a constant source of concern in coupling HPLC with mass spectrometry. The atmospheric pressure ionization (API) electrospray and API-ionspray ion sources can handle effectively the liquid flow rates encountered in microbore-packed (5-10 $\mu \mathrm{L} / \mathrm{min})$ and conventional $1-\mathrm{mm}$ i.d. $(40-50$ $\mu \mathrm{L} /$ min) HPLC columns, respectively [17]. The potential of HPLC/API-ionspray for the analysis of small dynorphin-related peptides $[18,19]$ and protein digests [20] was demonstrated recently. On the other hand, off-line HPLC/MS enjoys the advantage that mass spectrometric analysis of collected fractions is not limited to any specific ionization method. For over a decade, our research on the analysis of endogenous neuropeptides from biological samples has relied successfully on the off-line HPLC/MS combination [21]. Therefore, for evaluation of this new mode of ionization, it was appropriate to use similar sample-handling conditions.

The motivation for the present investigation is the fact that the intensity of the molecular ion signal in the more extensively used FAB/MS method is dependent on the relative hydrophobicity/hydrophilicity of various chemical constituents (analyte, matrix, impurities, etc.) present on the FAB probe tip [22]. Hydrophobic peptides preferentially occupy the surface of the FAB matrix and thus are ionized more readily. Because of this phenomenon and because of the multicomponent nature of a biological extract, many of the endogenous neuropeptides in tissue extracts are often difficult to ionize by using FAB, especially when present in low amounts (picomole and less). Furthermore, chemical noise produced by the FAB matrix [23] and other biological compounds present in the tissue extract begins to interfere at the picomole level.

The peptides studied here are important because they play crucial roles in various biochemical and neurochemical processes [24]. Their concentration in body fluids and tissues has been correlated with various psychiatric and metabolic disorders [25]. It is crucial to gain an understanding of the mass spectrometric behavior of these endogenous peptides before their concentration can be monitored accurately in body tissues and fluids.

Most laboratories use non-mass spectrometry methods, such as radioreceptorassay or radioimmunoassay, either alone or in combination with HPLC to analyze endogenous peptides [26]. Although those methods possess high detection sensitivity (picomole to fentomole, respectively), the claim of their high molecular specificity cannot be supported. Those assays exhibit varying degrees of cross-reactivities because they are based only on a receptor-binding or an antigen-antibody reaction, both of which cannot be highly specific to an amino acid sequence of a peptide. The greater complexity of several different, endogenous, structurally closely related neuropeptides that belong to the three opioid families demands the use of unambiguous sequence-specific analytical methods for identification and quantification of those peptides.

\section{Experimental}

Materials. All synthetic peptides studied here were purchased from Sigma Chemical Co. (St. Louis, MO), and were used without further purification. $\left[{ }^{2} \mathrm{H}_{5}\right]-$ 
Phenylalanine was from Merck (St. Louis, MO), and ditertbutyl dicarbonate from Fluka Chemical Corp. (Ronkonkoma, NY).

The deuterated peptide internal standard, $\left[{ }^{2} \mathrm{H}_{5}-\right.$ ${ }^{4} \mathrm{Phe}-\mathrm{ME}$, used in the quantification of $\mathrm{ME}$ was synthesized using the solid-phase peptide synthesis (SPPS) procedure on an Applied Biosystems (Foster City, CA) Model $430 \mathrm{~A}$ peptide synthesizer [27]. The $t$-butoxycarbonyl derivative of $\left[{ }^{2} \mathrm{H}_{5}\right]$-phenylalanine was synthesized according to the literature procedure [28]. After completion of the SPPS, the pentapeptide resin was treated with hydrofluoric acid (by Immunodynamics, San Diego, CA) to deblock and remove the pentapeptide from the resin. The crude $\left[{ }^{2} \mathrm{H}_{5}{ }^{4} \mathrm{Phe}\right]-\mathrm{ME}$ was purified by reversed-phase(RP)-HPLC, and its purity was determined by FAB/MS.

Three human pituitaries were obtained during autopsy and stored at $-70^{\circ} \mathrm{C}$ until processed as described below. Canine pituitary tissue was obtained under National Institutes of Health guidelines in the necropsy laboratory of the Department of Comparative Medicine.

Tissue extraction and purification. The procedure used here for tissue extraction and purification was described in detail elsewhere [27]. In brief, the pituitary tissue was homogenized in cold $\left(4^{\circ} \mathrm{C}\right) 1 \mathrm{~N}$ acetic acid in a Polytron (Brinkman, Westbury, NY; setting $=6$ ). After equilibration at $4^{\circ} \mathrm{C}$ for $2 \mathrm{~h}$, the homogenate was centrifuged $(131,000 \times g, 30 \mathrm{~min})$. The supernatant was applied to an octadecylsilyl (ODS) RP-SepPak disposable cartridge (Waters Associates, Milford, MA), and eluted with a 50:50 (v:v) acetonitrile $\left(\mathrm{CH}_{3} \mathrm{CN}\right): 0.1 \%$ trifluoroacetic acid solvent mixture to prepare a sample enriched in oligopeptides.

The peptide-rich fraction was separated into individual fractions with a gradient ODS RP-HPLC. Triethylamine formate (TEAF; $40 \mathrm{mM}$; $\mathrm{pH}$ 3.1) was used as the volatile buffer and $\mathrm{CH}_{3} \mathrm{CN}$ as the organic modifier [29]. Ninety fractions were collected at 1-min intervals. For example, synthetic ME and $\beta E$ eluted at 24 and $73 \mathrm{~min}$, respectively. The ME fraction was purified further by an additional chromatography step by using isocratic RP-HPLC, which employed a synthetic polymer (polystyrene-polydivinylbenzene; Polymer Laboratories, Amherst, MA) column [27] and a $16: 84(\mathrm{v}: \mathrm{v}) \mathrm{CH}_{3} \mathrm{CN}$ : TEAF solvent mixture as an eluent.

Mass spectrometry. All experiments were conducted on a prototype VG BioQ mass spectrometer operating in the positive ion mode and at unit mass resolution. The instrument is a single quadrupole mass analyzer with a mass range for singly charged ions of ca. 3000 $\mathrm{u}$, and was outfitted with an API-electrospray ion source and a minicomputer-based VG 11-250 M + data system. The spectra were obtained by scanning the instrument from $10-2000 \mathrm{u}$ in $10 \mathrm{~s}$. The mass scale was calibrated with a separate introduction of myoglobin (average $M_{r}=16,950.5 \mathrm{Da}$ ), which gives a se- ries of multiply charged molecular ion peaks in the required mass range.

The neuropeptides were dissolved in a $50: 50(v: v)$ methanol : water solvent containing $1 \%$ acetic acid to provide a concentration of ca. $30 \mathrm{pmol} / \mu \mathrm{L}$. An aliquot $(10 \mu \mathrm{L})$ of this solution was injected into a continuous flow ( $4 \mu \mathrm{L} / \mathrm{min}$ ) of the same solvent entering the ion source.

To analyze endogenous $\mathrm{ME}$, each pituitary extract lyophilizate was dissolved in $50 \mu \mathrm{L}$ of the electrospray solvent, and $10 \mu \mathrm{L}$ was introduced into the ion source as discussed above. The instrument was scanned over the narrow mass range 570-584 $u$ to collect the ion current due to the $[\mathrm{M}+\mathrm{H}]^{+}$ions of $\mathrm{ME}$ and $\left[{ }^{2} \mathrm{H}_{5}\right.$ ${ }^{4}$ Phe]-ME. A total of 20 scans was accumulated within ca. $75 \mathrm{~s}$ by operating the data system in the multichannel analyzer mode. Approximately $5 \mu \mathrm{L}$ of the sample (equivalent to $10 \%$ of the original sample) was consumed during the analysis.

Endogenous $\beta E$ from the human pituitary extract was analyzed in a similar fashion by scanning the mass spectrometer across the mass range 685-705 $u$ to collect the ion current due to the $[\mathrm{M}+5 \mathrm{H}]^{5+}$ in at $\mathrm{m} / \mathrm{z}$ 694, which is the most dominant ion in the electrospray mass spectrum of $\beta E$. The lyophilized HPLC fraction was dissolved in $500 \mu \mathrm{L}$ of the electrospray solvent, and was analyzed for $\beta E$ by electrospraying $10 \mu \mathrm{L}$ (equivalent to $2 \%$ of the original tissue) of that solution.

\section{Results and Discussion}

\section{Electrospray Mass Spectra}

Many of the peptides listed in Table 1 were previously characterized by FAB/MS [30-33]. Except for ME and leucine enkephalin (LE), all peptides contain basic amino acid residues. Electrospray has been shown to produce intact multiply charged molecular ion species [7-11, 14-16]. It is of interest to determine how these biologically important peptides behave when subjected to electrospray. That knowledge is helpful in their identification and quantification from extracts of body tissues and fluids. Table 2 lists the relative abundance of the different protonated molecular ions observed in the electrospray mass spectra of these neuropeptides. As representative examples, the mass spectra of $L E\left(M_{r}=555 \mathrm{Da}\right)$ and $\beta E\left(M_{r}=3463 \mathrm{Da}\right)$ are illustrated in Figures 1 and 2, respectively. Approximately $7 \%$ (equivalent to $20 \mathrm{pmol}$ ) of the total amount $(=300 \mathrm{pmol})$ of each peptide injected into the ion source was consumcd in obtaining these singlescan spectra. Unlike FAB mass spectra, the electrospray spectra of the peptides of Table 1 are relatively noise-free. The most significant feature of these electrospray spectra (except for LE and ME) is the presence of a series of multiply charged molecular ions.

The spectra also contain ions at the low mass range (see Figures 1 and 2) that probably stem from other constituents present in the solvent stream. For exam- 
Table 2. Electrospray mass spectra of neuropeptides

\begin{tabular}{|c|c|c|c|c|c|c|c|}
\hline \multirow[b]{2}{*}{ Neuropeptide } & \multirow{2}{*}{$\begin{array}{l}\text { Number of } \\
\text { basic amino } \\
\text { acid residues }\end{array}$} & \multicolumn{6}{|c|}{ Relative abundance } \\
\hline & & {$\left[\mathrm{M}+\mathrm{HI}^{+}\right.$} & {$[\mathrm{M}+2 \mathrm{H}]^{2+}$} & {$[\mathrm{M}+3 \mathrm{H}]^{3+}$} & {$[\mathrm{M}+4 \mathrm{H}]^{4+}$} & {$[\mathrm{M}+5 \mathrm{H}]^{5+}$} & {$[\mathrm{M}+6 \mathrm{H}]^{6+}$} \\
\hline$\overline{\mathrm{LE}}$ & 0 & 100 & - & - & - & - & - \\
\hline ME & 0 & 100 & - & - & - & - & - \\
\hline ME-Lys-Lys & 2 & 4 & 100 & 5 & - & - & - \\
\hline Dynorphin $A_{1-8}$ & 2 & $<1$ & 100 & 8 & - & - & - \\
\hline Dynorphin $A_{1.9}$ & 3 & $<1$ & 12 & 100 & - & - & - \\
\hline Dynorphin $\wedge_{1-10}$ & 3 & $\approx 1$ & 17 & 100 & - & - & - \\
\hline Dynorphin $A_{1-13}$ & 5 & - & 3 & 67 & 100 & - & - \\
\hline Dynorphin $A_{1-17}$ & 5 & - & 1 & 15 & 100 & $<1$ & - \\
\hline Dynorphin $B_{1-13}$ & 3 & - & 5 & 100 & 3 & - & - \\
\hline$\beta$-Endorphin ${ }_{1-31}$ & 5 & - & - & 1 & 29 & 100 & 26 \\
\hline
\end{tabular}

ple, the ions at $m / z 160,178,220$, and 256 probably are the solvent adducts having the structures $\left[\left(\mathrm{CH}_{3} \mathrm{OH}\right)_{5}\right]^{+}, \quad\left[\left(\mathrm{CH}_{3} \mathrm{OH}\right)_{5} \mathrm{H}_{2} \mathrm{O}\right]^{+}, \quad\left[\left(\mathrm{CH}_{3} \mathrm{OH}\right)_{5}\right.$. $\left.\mathrm{CH}_{3} \mathrm{COOH}\right]^{+}$, and $\left[\left(\mathrm{CH}_{3} \mathrm{OH}\right)_{5}\left(\mathrm{CH}_{3} \mathrm{COOH}\right) \mathrm{H}_{2} \mathrm{O}\right]^{+}$, respectively.

Multiple-charging of the peptide results from multiple protonation of the parent molecule to yield even-electron ions of the general nature $[\mathrm{M}+n \mathrm{H}]^{n+}$. The basic amino acids such as Lys and Arg play an important role in multiple-charging of polypeptides $[10,14,16,34]$. The influence of these basic residues on the electrospray spectra discussed here is also obvious. LE (Figure 1) and ME, which lack these basic residues, yield a singly protonated molecule only; in contrast, the peptides that contain basic amino acid residues produce a series of multiply charged molecular ion species. As the $M_{r}$ increases from $L E$ to $\beta E$, the singly charged $[\mathrm{M}+\mathrm{H}]^{+}$species disappear. Also, ion current increases concomitantly with the increase in the number of charges until a maximum is reached, and then decreases rapidly. Furthermore, except for dynorphin $A_{1-17}$ and dynorphin $A_{1-13}$, a proportionality exists between the number of charges of the most abundant ion among those clusters and the number of basic amino acid units present in the peptide. For example, for ME-Lys-Lys and dynorphin $A_{1-8}$, both of which contain two basic amino acid units, the most abundant ion in their electrospray mass spectra is the $[\mathrm{M}+2 \mathrm{H}]^{2+}$ ion.

The proportionality between the number of charges

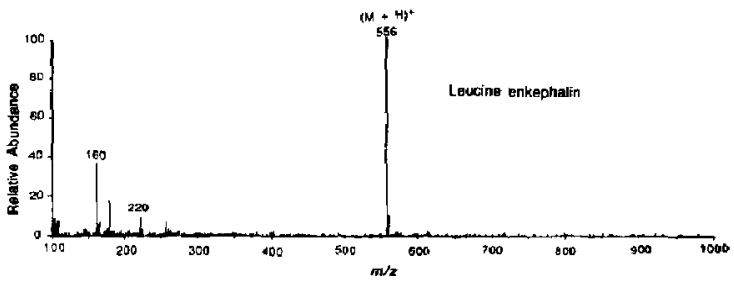

Figure 1. The electrospray mass spectrum of synthetic leucine enkephalin. The $[\mathrm{M}+\mathrm{H}]^{+}$ion appears at $m / z 556$. and the number of basic amino acids is not as straightforward to rationalize as it appears in the above discussion. If that were the case, we would expect a one-to-one correspondence between the number of charges of the most abundant multiply charged ion and the number of the protonation sites (i.e., the number of basic amino acids plus the $\mathrm{N}$ terminal site). Clearly, other factors, such as higher order structures, charge density, charge repulsion between the neighboring basic amino acids, etc., play a role in determining the charge state of a molecule. The dependence of an ion's desorption rate on droplet surface charge density [35], the presence of disulfide bonds in a peptide $[16,35]$, the voltage applied to the nozzle-skimmer at the entrance orifice to the mass spectrometer [36], and the solvents used in the electrospray process [34] also affect the charge state of a molecule.

Another interesting feature of the electrospray spectra is the absence of any amino acid sequencespecific fragment ions. A significant implication of this deficiency, as will be demonstrated later for $M E$ and $\beta \mathrm{E}$, is the potential increase in the detection sensitiv-

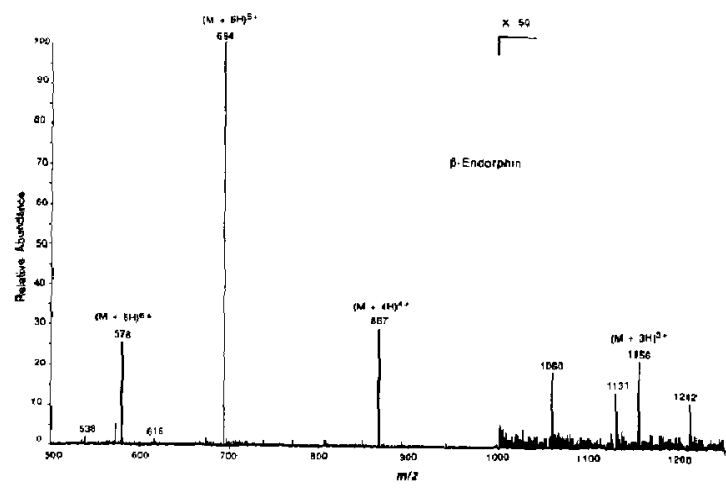

Figure 2. The electrospray mass spectrum of synthetic $\beta-p n-$ dorphin. The $[\mathbf{M}+3 \mathrm{H}]^{3+},[\mathbf{M}+4 \mathrm{H}]^{4+},[\mathbf{M}+5 \mathrm{H}]^{5+}$, and $[\mathbf{M}+$ $6 \mathrm{H}]^{6+}$ ions appear at $m / z 1156,867,694$, and 578 , respectively. 
ity for quantification measurements based on electrospray mass spectrometry, because the total ion current is concentrated within only a few of the intact molecular ion species.

On the other hand, the lack of any peptide bond fragmentation could be a serious limitation of electrospray mass spectrometry for structural analysis. Other than obtaining the $M_{r}$ value of a peptide from the multiply charged molecular ion species, it is not possible to arrive at its amino acid sequence. However, efforts are being made to induce peptide bond fragmentation of the intact multiply charged molecular ion species formed in electrospray by collisions with a neutral target [37, 38]. This development, in combination with tandem mass spectrometry (MS/MS), would enhance the potential of electrospray for structural analysis of biomolecules. Several peptides listed in Table 1 have been sequenced by us with ease by using FAB ionization alone $[30,32]$ or coupled with the $B / E$ linked-field MS/MS technique [31, 32].

\section{Quantification of Methionine Enkephalin}

Electrospray mass spectrometry represents a significant advance in the use of soft ionization techniques for the analysis of thermally sensitive compounds. So far, electrospray mass spectrometry has been applied mainly to characterize large peptides and proteins based on their $M$, determination. We present here the application of electrospray mass spectrometry to quantify endogenous $\mathrm{ME}$ and $\beta \mathrm{E}$.

Calibration curve. As discussed above, the electrospray spectrum of ME is very simple, and yields only the $[\mathrm{M}+\mathrm{H}]^{+}$ion and no indication of fragment ions characteristic of the $\mathrm{ME}$ sequence. The ion current due to that $[\mathrm{M}+\mathrm{H}]^{+}$ion was used here to obtain a calibration curve.

For the success of any quantification method, it is obligatory to incorporate an internal standard very early in the overall analysis scheme. For example, the appropriate internal standard must be added before tissue extraction and homogenization, and must participate in the separation and analysis steps of the procedure [27, 39]. Thus, any losses of endogenous peptides during these steps and inconsistency in the analysis are compensated for appropriately.

The criteria for choosing an internal standard demand that its amino acid sequence and chemical and physical properties are identical to, and its mass is different from, the native peptide. Thus, stable isotope-labeled compounds are the most ideal internal standards because they co-elute during HPLC with, and exhibit the same mass spectrometric response as, the target peptide. With these criteria in mind, $\left[{ }^{2} \mathrm{H}_{5}-\right.$ ${ }^{4} \mathrm{Phe}-\mathrm{ME}$ (in which the benzene ring hydrogen atoms of the Phe residue were replaced with deuterium atoms to shift the mass of $[\mathrm{M}+\mathrm{H}]^{+}$by $5 \mathrm{u}$ ) was used as the internal standard in the present study. Previ- ous studies from our laboratory have used ${ }^{18} \mathrm{O}$-isotope-labeled (at the C-terminus carboxylic group) $\mathrm{ME}$ as an internal standard [39]. However, back-exchange of ${ }^{18} \mathrm{O}$ under basic $\mathrm{pH}$ conditions limits its use. Incorporation of deuterium atoms in the benzene ring overcame that back-exchange problem.

To generate a calibration curve, a series of $\mathrm{ME}$ solutions in the concentration range of $125-4000$ $\mathrm{pg} / \mu \mathrm{L}$ (corresponding to ca. $220 \mathrm{fmol}-7 \mathrm{pmol} / \mu \mathrm{L}$ ) was prepared in the electrospray solvent. Each solution also contained a fixed amount $(1 \mu \mathrm{g})$ of $\left[{ }^{2} \mathrm{H}_{5}\right.$ $\left.{ }^{4} \mathrm{Phe}\right]-\mathrm{ME}$ internal standard. These solutions were analyzed as described in the Experimental section, and the ion current due to the $[\mathrm{M}+\mathrm{H}]^{+}$ion of $\mathrm{ME}$ and that of $\left[^{2} \mathrm{H}_{5}{ }^{4} \mathrm{Phe}\right]-\mathrm{ME}$ was recorded. Although selected ion monitoring generally provides more detection sensitivity than a narrow mass scan, we preferred the latter in this first case study to ensure by visual inspection that the indicated masses were free from any interference. Only $5 \mu \mathrm{L}$ of the injected peptide solution was consumed in obtaining these data. A plot of the ratio of $\mathrm{ME} /\left[^{2} \mathrm{H}_{5}{ }^{4} \mathrm{Phe}\right]-\mathrm{ME}[\mathrm{M}+\mathrm{H}]^{+}$ion currents versus pmol ME provided the calibration curve (not shown), with a linear correlation coefficient of 0.999 . This curve allows detection of as low as ca. 1 pmol ME. The detection sensitivity of the present method is comparable or superior to the sensitivity of the previously reported negative ion [40] and positive ion [27] FAB/MS methods. A significant advantage of the present electrospray method over those $F A B / M S$ methods is an improved signal-to-noise ratio, which increased the confidence level and detection sensitivity of the measurement. The narrow mass scan of the $[\mathrm{M}+\mathrm{H}]^{+}$ion of the lowest concentration studied is shown in Figure $3 \mathrm{a}$ to demonstrate the excellent signal-to-noise level at that low amount of $\mathrm{ME}$.

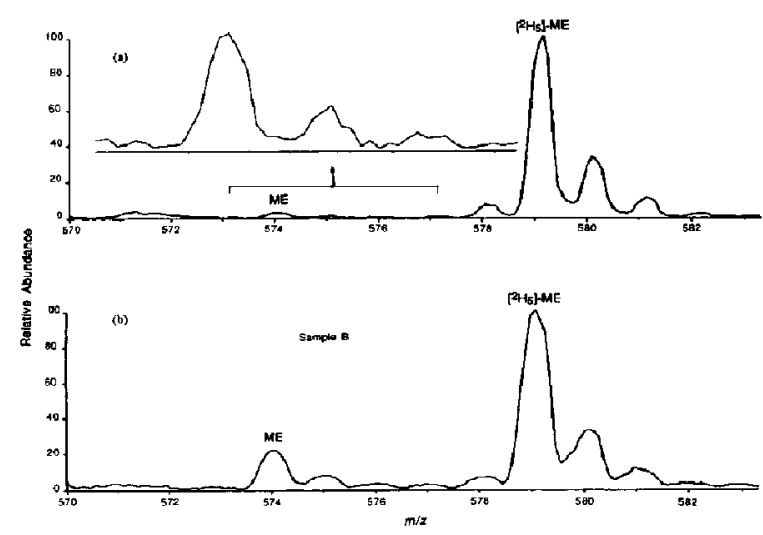

Figure 3. (a) A narrow-scan electrospray mass spectrum of a solution containing $125 \mathrm{pg} / \mu \mathrm{L}$ synthetic $\mathrm{ME}$ and $4 \mathrm{ng} / \mu \mathrm{L}\left[{ }^{2} \mathrm{H}_{5}\right.$ ${ }^{4}$ Phe]-ME. Approximately $0.625 \mathrm{ng} \mathrm{ME}$ (equivalent to ca. 1.1 pmol) was consumed in acquiring this spectrum; (b) the electrospray mass spectrum analysis of a human pituitary extract (sample B). 
Table 3. Electrospray mass spectrometry analysis of methionine enkephalin in pituitary extracts

\begin{tabular}{lccc}
\hline Sample & $\begin{array}{c}\text { Total } \\
\text { weight } \\
\text { (g) }\end{array}$ & $\begin{array}{c}\text { Proteins } \\
\text { (\% of total } \\
\text { weight) }\end{array}$ & $\begin{array}{c}\text { Methionine } \\
\text { enkephalin } \\
\text { (pmol/mg protein) }\end{array}$ \\
\hline \hline Human pituitaries & & & \\
A & 0.305 & 15.9 & 9.1 \\
B & 0.305 & 15.9 & 8.2 \\
C & 0.353 & 17.6 & 4.7 \\
Canine pituitary & 0.195 & 20.1 & 39.8 \\
\hline
\end{tabular}

Analysis of ME in individual human and canine pituitary extracts. Methionine enkephalin-like immunoreactivity was demonstrated in the human pituitary gland [41]. Recently, unambiguous evidence of the presence of ME was reported in human pituitary extracts by $\mathrm{FAB}$ and $\mathrm{B} / \mathrm{E}$ linked-field scan mass spectrometry techniques [27]. The present electrospray mass spectrometry method was applied to quantify endogenous ME in one whole canine and three human pituitaries. To determine the reproducibility of the quantitative method, one human pituitary was divided into two portions (samples A and B). Because the other two human pituitaries were small, they were combined to provide sample $C$. One microgram of $\left[{ }^{2} \mathrm{H}_{5}{ }^{4} \mathrm{Phe}\right]-\mathrm{ME}$ was added to each sample, and ME was extracted and purified as described above. The canine pituitary was also analyzed in a similar fashion.

Table 3 contains the data from the electrospray mass spectrometry analysis of ME from these pituitary extracts. An electrospray mass spectrum of the solvent blank was also obtained between each sample to ensure that no carryover occurred from the previous sample. A typical example demonstrating the signal-to-noise level of the analysis of a biological sample (sample $B$ ) is shown in Figure $3 b$. The three human pituitary samples $A, B$, and $C$ contained 9.1, 8.2 , and $4.7 \mathrm{pmol} \mathrm{ME} / \mathrm{mg}$ protein, respectively. The corresponding amount in one canine pituitary was $39.8 \mathrm{pmol} \mathrm{ME} / \mathrm{mg}$ protein. The variation (ca. $\pm 5 \%$ ) in the amounts of ME determined in the two samples $A$ and $B$ of the same pituitary reflects the good reproducibility of the overall experimental steps of this quantification procedure.

\section{Quantification of $\beta$-Endorphin}

$\beta$-Endorphin is an opioid-active peptide consisting of 31 amino acids, and is derived metabolically from its large precursor, pro-opiomelanocortin [42]. Although several other forms of $\beta \mathrm{E}$ exist endogenously (e.g., acetyl $-\beta E$, acetyl- and non-acetyl $-\beta E$ fragments $1-26$ and 1-27), opioid activity is attributable to $\beta \mathrm{E}_{1-31}$. Therefore, a clear understanding of the physiological functions of $\beta \mathrm{E}$ demands a precise and accurate knowledge of its distribution in body tissues and fluids.

Because of the hydrophilic character of $\beta \mathrm{E}$, as measured by the Bull and Breese index [43] $(=+930$ for $\beta \mathrm{E}[44])$, it has been difficult to analyze by FAB/MS. Furthermore, the $\mathrm{M}_{r}(=3463 \mathrm{Da})$ of $\beta \mathrm{E}$ is beyond the most sensitive mass range of many mass spectrometers. To circumvent these difficulties, we previously trypsinolyzed $\beta \mathrm{E}$ to cleave it into smaller peptide fragments $[44,45]$. The $[\mathrm{M}+\mathrm{H}]^{+}$ion of the tryptic peptide $\beta \mathrm{E}_{21-24}$ (NAIIK) [44] and the transition $[\mathrm{NAIIK}+\mathrm{H}]^{+} \rightarrow \mathrm{NAI}^{+}[45]$ were monitored separately by $\mathrm{FAB} / \mathrm{MS}$ to quantify endogenous human $\beta \mathrm{E}$. The detection sensitivities of these two quantification methods were 86 and $580 \mathrm{fmol} \beta \mathrm{E}$, respectively.

Another feasible approach to quantifying $\beta \mathrm{E}$ is to monitor multiply charged molecular ions. The ion current due to the $[\mathrm{M}+2 \mathrm{H}]^{2+}$ ion of $\beta \mathrm{E}$ was recorded by Voyksner and Pack [46] using thermospray mass spectrometry and by us using FAB/MS [45]. These two methods were capable of quantifying $\beta \mathrm{E}$ down to 10 and 3 pmol, respectively.

As discussed above and shown in Figure 2, electrospraying $\beta \mathrm{E}$ generates several different multiply charged species of intact $\beta E$. An ion bearing five positive charges $(m / z 694)$ is the most dominant of these multiply charged species. This abundant ion is the logical choice to quantify endogenous $\beta \mathrm{E}$. For these measurements, the electrospray spectrum was acquired in the narrow mass range (again to show absence of interference) encompassing the $[M+$ $5 \mathrm{H}]^{5+}$ ion. An external calibration curve (not shown; linear correlation coefficient $=0.999$ ) in the concentration range of $5 \mathrm{fmol}-50$ pmol was obtained by plotting the ion current due to the $[\mathrm{M}+5 \mathrm{H}]^{5+}$ ion versus the amount of $\beta \mathrm{E}$. The detection sensitivity of the present method is ca. 5 fmol of synthetic $\beta E$. Thus, the present method is approximately 17 times more sensitive than our previously reported FAB/MS method [44] and also does not require the trypsinolysis step. The electrospray mass spectrometry analysis (see inset of Figure 4) of the $\beta \mathrm{E}$ fraction indicated $660 \mathrm{fmol}$ $\beta \mathrm{E} / \mathrm{mg}$ protein.

\section{Full-Scan Electrospray Mass Spectra of Pituitary Extract}

A biological sample is always complex in nature and may contain different impurities, even after several chromatographic sleps [27]. The chemical noise due to these impurities and the liquid matrix is a limiting factor in the FAB/MS analysis of peptides. Although we were able to obtain a good electrospray mass spectrometry signal for the $[\mathrm{M}+\mathrm{H}]^{+}$ion of $\mathrm{ME}$ in the pituitary extract of sample $B$ (Figure $3 b$ ) when a narrow mass range was used for data acquisition, it was also important to determine the electrospray mass spectrometry response of ME compared to the solvent and biological impurities. The full-scan positive ion electrospray mass spectra in the mass range 200-1000 $u$ of the ME RP-HPLC fractions of the two separate pituitary samples $B$ and $C$ are illustrated in Figure 5. 


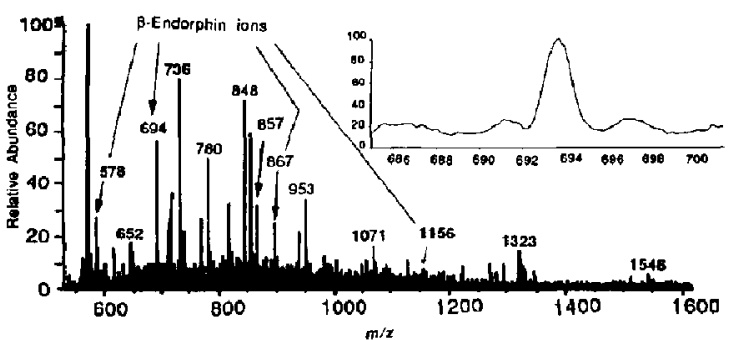

Figure 4. A full-scan electrospray mass spectrum of the RPHPLC $\beta$ E fraction of a human pituitary extract. The multiply charged molecular ions corresponding to the addition of $6,5,4$, and 3 protons are seen at $m / z 578,694,867$, and 1156, respectively. The inset shows the electrospray mass spectrometry analysis of endogenous b-endorphin in a human pituitary extract.

Both spectra exhibit low background noise compared to $\mathrm{FAB} / \mathrm{MS}$, and display strong signals due to the $[\mathrm{M}+\mathrm{H}]^{+}$ions of $\mathrm{ME}$ and $\left[{ }^{2} \mathrm{H}_{5}{ }^{4}\right.$ Phe]-ME, with a signal-to-noise ratio greater than $3: 1$ for the $[\mathrm{M}+\mathrm{H}]^{+}$ ion of ME. These spectra were acquired with one-tenth (equivalent to ca. 40 and $30 \mathrm{pmol} \mathrm{ME}$, respectively) of the original-amount of ME present in those samples. The amount of $\left[{ }^{2} \mathrm{H}_{5}{ }^{4} \mathrm{Phe}\right]-\mathrm{ME}$ present in these two samples was ca. 170 pmol.

We also obtained the full-scan electrospray mass spectrum of the $\beta \mathrm{E}$ fraction from the gradient RPHPLC step. That mass spectrum (shown in Figure 4) is characterized by the presence of a large number of non- $\beta E$ ions. No difficulty, however, was encountered in identifying $\beta E$ in that mass spectrum. The multiply charged molecular ions characteristic of $\beta \mathrm{E}$, corresponding to the addition of $6,5,4$, and 3 protons, were clearly distinguishable in that spectrum at $m / z 578,694,867$, and 1156 , respectively. It is significant to note that FAB analysis of a similar pituitary sample failed to produce any ion related to $\beta \mathrm{E}$.

\section{Conclusions}

The data presented in this article demonstrate the utility of electrospray mass spectrometry in characterizing and quantifying opioid peptides extracted from

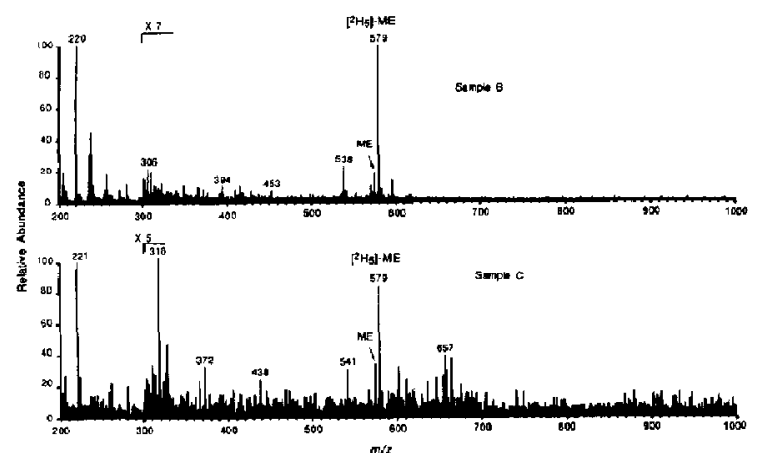

Figure 5. Full-scan electrospray mass spectra of two human pituitary samples (B and C). a biological matrix. Highlights of the technique are low background noise and formation of abundant multiply charged molecular species. The advantage of electrospray is that an instrument with a limited mass range can be used effectively to quantify even large peptides, as demonstrated here in the case of human $\beta \mathrm{E}$. Although the multiply charged molecular ions are characteristic of an analyte, they do not provide any amino acid sequence information of the target peptide. Only MS/MS can furnish unambiguous sequence-specific information from a selected molecular ion $[26,27,39,40]$. Our future plans to quantify $\mathrm{ME}$ and $\beta \mathrm{E}$ include the use of electrospray in combination with selected reaction monitoring and collisionactivated dissociation to monitor a sequence-specific ion formed in a field-free region.

\section{Acknowledgments}

The authors gratefully acknowledge the financial support of the National Instifutes of Health (GM 26666) and the Molecular Resource Center ( $R$. Sumrada) for the synthesis of $\left[{ }^{2} \mathrm{H}_{5}{ }^{4} \mathrm{Phe}\right]$ ME.

\section{References}

1. Barber, M.; Bordoli, R. S.; Sedgwick, R. D.; Tyler, A. N. J. Chem. Soc. Chem. Commun. 1981, 325-327.

2. Benninghoven, A.; Rudenaur, F. G.; Werner, H. W. Secandary Ion Mass Spectrometry; Wiley-Interscience: New York, 1987.

3. Beckey, H. D. Principles of Field Desorption Mass Spectrometry; Pergamon Press: Oxford, 1977.

4. Karas, M.; Hillenkamp, F. Anal. Chem. 1988, 60, 2299-2301.

5. Sundquist, B.; Macfarlane, R. D. Mass Spectrom. Rev, 1985, 4, 421-460

6. Blakley, C. R.; Carmody, J. J.; Vestal, M. L. Anal. Chem. $1980,52,1636-1641$.

7. Whitehouse, C. M.; Dreyer, R. N.; Yamashita, M.; Fenn, J. B. Anal. Chem. 1985, 57, 675-679.

8. Fenn, J. B.; Mann, M.; Meng, C. K.; Wong, S. F.; Whitehouse, C. M. Science 1989, 246, 64-71.

9. Wong, S. F.; Meng, C. K.; Fenn, J. B. J. Chem. Phys. 1988, 92, 546-550.

10. Bruins, A. P.; Covey, T. R.; Henion, J. D. Anal. Chem. 1987, $59,2642-2646$

11. Covey, T. R.; Bonner, R. F.; Shushan, B. I.; Henion, J. D. Rapid Commun. Mass Spectrom. 1988, 2, 249-256.

12. Dole, M.; Mack, L. L.; Hines, R. L.; Mobley, R. C.; Ferguson, L. P.; Alice, M. B. J. Chem. Phys. 1968, 49, 2240-2249.

13. Mack, L. L.; Kralik, P.; Rheude, A,; Dole, M. J. Chem. Phys. 1970, 52, 4977-4986.

14. Loo, J. A.; Udseth, H. R.; Smith, R. D. Anal. Biochem. 1989, $179,404-412$.

15. Chowdhury, S. K.; Katta, V.; Chait, B. T. Rapid Commun. Mass Spectrom. 1990, 4, 81-87.

16. Loo, J. A.; Edmonds, C. G.; Udseth, H. R.; Smith, R. D. Antal. Chem. 1990, 62, 693-698.

17. Covey, T. R.; Lee, E. D.; Bruins, A. P.; Henion, J. D. Anal. Chem. 1986, 58, 1451A-1461A. Huang, E. C.; Wachs, T.; Conboy, J. J.; Henion, J. D. Anal. Chem. 1990, 62, 713A-725A.

18. Lee, E. D.; Muck, W.; Henion, J. D.; Covey, T. R. J. Chromatogr. 1988, 458, 313-321. 
19. Muck, W.; Henion, J. D. J. Chromatogr. 1989, 495, 41-59.

20. Huang, E. C.; Henion, J. D. J. Am. Soc Mass Spectrom. 1990, $1,158-165$.

21. Desiderio, D. M. In Mass Spectrometry of Peptides; Desiderio, D. M., Ed.; CRC Press: Boca Raton, FL, 1990; pp. 367-402.

22. Naylor, S.; Findeis, A. F.; Gibson, B. W.; Williams, D. H. J. Am. Chem, Soc. 1986, 108, 6359-6363.

23. Dass, C.; Desiderio, D. M. Anal. Chem. 1988, 60, 2723-2729.

24. Martin, J. B.; Brownstein, M. J.: Krieger, D. T. Brain Peptides - Update; Wiley-Interscience: New York, 1987.

25. Martin, J. B.; Barchas, J. D. Neuropeptides in Neurological and Psychiatric Diseases; Raven Press: New York, 1986.

26. Desiderio, D. M. Analysis of Neuropeptides by Liquid Chromatography and Mass Spectrometry; Elsevier: Amsterdam, 1984.

27. Kusmierz, J. J.; Sumrada, R,; Desiderio, D. M. Anal. Chem., 1990, 62, 2395-2400.

28. Itoh, M.; Hagiwara, D; Kamiya, T. Tetrahedron Lett. 1975, 4393-4394.

29. Fridland, G. H.; Desiderio, D. M. I. Chromatogr. Biomed. Appl. 1986, 379, 251-268.

30. Dass, C.; Desiderio, D. M. Anal. Biochem. 1987, 163, 52-66.

31. Dass, C; Desiderio, D. M. Int. J. Mass Spectrom. Ion Processes 1989, 92, 267-287.

32. Dass, C. In Mass Spectrometry of Peptides; Desiderio, D. M., Ed.; CRC Press: Boca Raton, FL, 1990; pp. 327-346.

33. Desiderio, D. M. Int. J. Mass Spectrom. Ion Processes 1986, $74,217-233$
34. Loo, J. A.; Udseth, H. R.; Smith, R, D. Biomed. Environ. Mass Spectrom. 1988, 17, 411-412.

35. Fenn, J. B.; Mann, M.; Meng, C. K.; Wong, S. F,; Whitehouse, C. M. Mass Spectrom. Rev. 1990, 9, 37-70.

36. Loo, J. A.; Udseth, H. R.; Smith, R. D. Rapid Commun. Mass Spectrom. 1988, 2, $207 \cdot 210$.

37. Barinaga, C.J.; Edmonds, C. G.; Udseth, H. R.; Smith, R. D. Rapid Commun. Mass Spectrom, 1989, 3, 160-164.

38. Smith, R. D.; Barinaga, C. J. Rapid Commun. Mass Spectrom. $1990,4,54-57$.

39. Desiderio, D. M.; Kai, M. Biomed. Mass Spectrom. 1983, 10 , 471-479.

40. Tolun, E.; Dass, C.; Desiderio, D. M. Rapid Commun. Mass Spectrom. 1987, $1,77-79$

41. Gramsch, C.; Hollt, V.; Mehraien, P.; Pasi, A.; Herz, A. Brain Res. 1979, 171, 261-270.

42. Numa, S. In Peptides, vol. 6; Udenfriend, S., Ed.; Academic: New York, 1984; pp. 1-23.

43. Bull, H. B.; Breese, K. Arch. Binchem. Biophys. 1974, 161. $665-670$.

44. Dass, C.; Fridland, G. H.; Tinsley, P. W.; Killmar, J. T.; Desiderio, D. M. Int. J. Pept. Prot. Res, 1989, 34, 81-87.

45. Dass, C.; Kusmierz, J. J.; Desiderio, D. M. Biomed. Environ. Mass Spectron., in press.

46. Voyksner, R. D.; Pack, T. W. Biomed, Enviton. Mass Spectrom. 1989, 18, 897-903. 